International Journal of Agriculture and Environmental Research

ISSN: 2455-6939

Volume: 07, Issue: 02 "March-April 2021"

\title{
CALLUS INDUCTION AND REGENERATION IN LEPISANTHES FRUTICOSA
}

\author{
${ }^{1 *}$ Zuraida Ab Rahman, ${ }^{2}$ Mohd Shukri Mat Ali, ${ }^{2}$ Mohd Norfaizal Ghazalli, ${ }^{3}$ Khadijah Awang, \\ ${ }^{1}$ Ayu Nazreena Othman, ${ }^{4}$ Amirah Balqis Amir Amran and ${ }^{4}$ Nurul Qistina Mohamed Bakri
}

\footnotetext{
${ }^{1}$ Biotechnology \& Nanotechnology Research Centre, Malaysian Agricultural Research and Development Institute, MARDI HQ, Persiaran MARDI-UPM, 43400 Serdang Selangor, Malaysia.

${ }^{2}$ Agrobiodiversity\& Environment Research Center, Malaysian Agricultural Research and Development Institute, MARDI HQ, Persiaran MARDI-UPM, 43400 Serdang Selangor, Malaysia.

${ }^{3}$ Industrial Crops Research Center, Malaysian Agricultural Research and Development Institute, MARDI Jerangau, 21810 Ajil, Terengganu, Malaysia

${ }^{4}$ School of Agriculture Science \& Biotechnology, Faculty of Bioresources and Food Industry, Universiti Sultan Zainal Abidin, Besut Campus, 22200, Besut, Terengganu, Malaysia

*Corresponding Author
}

DOI: https://doi.org/10.51193/IJAER.2021.7208

\begin{abstract}
In vitro leaves of Lepisanthes fruticosa cultured for callusing, then proliferated into somatic embryos and eventually regenerated plantlets. The optimal treatment for callus induction of Lepisanthes fruticose is $1.0 \mathrm{mg} / \mathrm{L} \mathrm{NAA}+0.2 \mathrm{mg} / \mathrm{L} \mathrm{2,4-} \mathrm{D.} \mathrm{The} \mathrm{callus} \mathrm{initiation} \mathrm{was} \mathrm{observed} \mathrm{in}$ medium containing plant growth regulators, 2,4-dichlorophenoxyacetic acid (2,4-D) and $\alpha$ Naphthalene acetic acid (NAA) either on its own or combined. At $0.2 \mathrm{mg} / \mathrm{L}$ and $1.0 \mathrm{mg} / \mathrm{L}$ of 2,4$\mathrm{D}$ and NAA, respectively, callus induction showed the highest rate (100\%) in WPM media. The callus showed no sign of browning after sub-cultured. Subculturing the callus onto a medium with $0.5 \mathrm{mg} / \mathrm{L}$ of Kinetin showed the highest proliferation rate (100\%) and improved the regeneration of somatic embryos, which produced the highest number of plantlets (21 plantlets). BAP with a concentration of 0.5 and $1.0 \mathrm{mg} / \mathrm{L}$ increase the browning incidence on the subcultured callus.
\end{abstract}

Keywords: Lepisanthes fruticosa, callus induction, regeneration 
International Journal of Agriculture and Environmental Research

ISSN: 2455-6939

Volume: 07, Issue: 02 "March-April 2021"

\section{INTRODUCTION}

Lepisanthes fruticose, or the local name is Ceri Terengganu is a small, woody shrub with fruits in deep red with $2 \mathrm{~cm}$ to $3 \mathrm{~cm}$ in diameter. The fruits are in clusters with approximately 20 fruits per bunch (Zuraida et al., 2018). It is a member of the family Sapindaceae and is in the genus Lepisanthes. The trees are usually 1.5 to $10 \mathrm{~m}$ tall, but they may reach a height of $14 \mathrm{~m}$. The twigs are reddish but turn into brown or silvery grey over time(Lim, 2013). The cultivation of this species is rare as it is underutilized despite having health-promoting benefits. Lepisanthes fruticose are recently discovered to have high antioxidant properties through a research by Hadijah et al., (2020) the plants can suppress MCF-7 and CRL1739 cells, which are human cancer cells with no toxicity found in normal cells. However, despite the plants' health potential, locals do not consume them but rather have the plants as ornamental plants (Looi et al., 2020). A primary emphasis of planting material must be readily accessible before this fruit tree can be commercialized, encompassing a micropropagation technique that can provide a good source of planting materials. Plant growth regulators are among the most critical factors for micropropagation success in terms of callus induction, proliferation rate, and plantlet regeneration. Plant growth regulators are widely used in tissue culture for callus, shoot induction, rooting and plant regeneration. Five groups of plant growth regulators are auxin, gibberellin, cytokinin, ethylene and abscisic acid. Therefore, plant growth regulators that were used in this study are Auxin ((2,4- D), 2,4-Dichlorophenoxyacetic acid and (NAA) 1-Naphthaleneacetic acid); Gibberellin; and Cytokinin ((BAP) Benzylaminopurine, and Kinetin). Cytokinin was reported to promote cell division and cell differentiation (Barciszewski J. et al., 1999). Auxin plays a vital role in cell elongation, division and differentiation, embryonic development and apical dominance (Balzan S. et al., 2014). According to Hedden P. 2017, gibberellin's function in tissue culture is to promote cell elongation, division and activation of developmental switches. For instance, between seed dormancy and germination phase.

However, if the concentration is not appropriate, the plant growth regulators can lead to failure. Thus, this study aimed to investigate the effect of different concentrations of different plant growth regulators in producing callus and regenerated plantlets.

\section{MATERIALS AND METHODS}

\section{Plant materials and culture conditions}

Tissue culture plantlets of Lepisanthes fruticosa via direct organogenesis were used as explants. The method of cultivating these plantlets were following method that has been established by Zuraida et (2018). The plantlets were culture on Semi-solid WPM media containing $1 \mathrm{mg} / \mathrm{L}$ BAP. Plantlets were left up to $6-10 \mathrm{~cm}$ tall and the leaves were taken to be cultured as an explant. All 
International Journal of Agriculture and Environmental Research

ISSN: 2455-6939

Volume: 07, Issue: 02 "March-April 2021"

the culture media in this study were adjusted to $\mathrm{pH} 5.8$ before they were solidified with gelrite agar, autoclaved at $121^{\circ} \mathrm{C}$ and $104 \mathrm{kPa}$ for $15 \mathrm{~min}$. The cultures were incubated in the culture room under white fluorescent light with a light intensity of 3000 lux and a photoperiod of $16 \mathrm{~h}$ at $25 \pm 2^{\circ} \mathrm{C}$.

\section{Callus induction, proliferation and regeneration}

The leaves of Lepisanthes fruticosa raised in vitro were cut into lengths of $2-3 \mathrm{~cm}$ and cultured on MS or WPM medium supplemented with varies plant growth regulator, 3\% sucrose and $3 \mathrm{~g} / \mathrm{L}$ phytogel (Figure 1a).For callus induction, the medium used was supplemented with 2,4dichlorophenoxyacetic acid (2,4-D) at concentrations of 0.2 and $0.5 \mathrm{mg} / \mathrm{L}$ and $\alpha$-Naphthalene acetic Acid (NAA) at $0,0.5,1.0,3.0$, and $5.0 \mathrm{mg} / \mathrm{L}$, with each growth regulator used on its own or in combination with one another as listed in Table 1. The cultures were maintained under dark condition. Callus induction success was expressed as percentage of callus induction, callus fresh weight and percentage of browning after a month of sub-cultured.

To investigate the effects of plant growth regulators on callus proliferation, the callus that was initiated from the treatments with $0.2 \mathrm{mg} / \mathrm{L} 2,4-\mathrm{D}$ or $0.2 \mathrm{mg} / \mathrm{LNAA}$ was sub-cultured three times at monthly intervals onto fresh media with different concentrations of NAA, 2,4-D, and BAP at concentrations $0.2,0.5$, and $1.0 \mathrm{mg} / \mathrm{L}$. The percentage of proliferation and degree of greening were recorded after 40days of culture. Percentage of browning was recorded at monthly intervals. To investigate the effects of plant growth regulators on callus proliferation, the callus that was initiated from the two treatments named $0.2 \mathrm{mg} / \mathrm{L} 2,4-\mathrm{D}+1.0 \mathrm{mg} / \mathrm{L}$ NAA or $0.2 \mathrm{mg} / \mathrm{L}$ 2,4-D+0.5 mg/L NAA was sub-cultured four times at monthly intervals onto same fresh media with different concentrations of NAA, 2,4-D, and BAP at concentrations $0.2,0.5$, and $1.0 \mathrm{mg} / \mathrm{L}$. The percentage of proliferation callus, greening embryos, browning and number of plantlets regenerated were recorded for the first month, second month, third month and fourth month of sub-cultured, respectively. For regeneration stage, selection green embryos were sub-cultured on treatment medium and the number of plantlets regenerated was recorded after 4 weeks. Regenerated shoots were then transferred to MS medium that was free of plant growth regulators for leaf development and root induction. The plantlets were individually transplanted in soil contained in poly bags and kept under controlled conditions in a net house with $75 \%$ shading. The survival rate of the plantlets was recorded after 6 weeks.

\section{Statistical analysis}

The data (25 replicates per treatment) were subjected to one-way analysis of variance (ANOVA) to assess treatment differences and interaction using the SPSS version 11.0. Significance of differences between means was tested by DMRT's Test ( $\mathrm{p} \leq 0.05)$. 
International Journal of Agriculture and Environmental Research

ISSN: 2455-6939

Volume: 07, Issue: 02 "March-April 2021"

\section{RESULTS AND DISCUSSION}

\section{Callus induction of Lepisanthes fruticosa}

In this study, the recurrence of callus induction for Lepisanthes fruticosa induced by different concentrations of NAA and 2,4-D for both MS media and WPM is shown in Table 1. The percentage for callus induction in MS media ranged from $10 \%$ to $100 \%$, while for WPM, the rate varied from $5 \%$ to a maximal induction of callus, which is $100 \%$ depending on the treatments. The most significant reading for callus induction was recorded among the treatments when the explants were treated with $1.0 \mathrm{mg} / \mathrm{L} \mathrm{NAA}+0.2 \mathrm{mg} / \mathrm{L} 2,4-\mathrm{D}$ for both media. This suggested that the treatment of $1.0 \mathrm{mg} / \mathrm{L} \mathrm{NAA}+0.2 \mathrm{mg} / \mathrm{L}$ 2,4-D (Figure 1b) is optimum for callus induction of Lepisanthes fruticosa. Besides, the results can be supported by research conducted by Duhoky \& Layla, (2013) that showed a high percentage of callus induction $(92.86 \%)$ when the explants are also treated with $0.2 \mathrm{mg} / \mathrm{L}$ of NAA but paired with $2.0 \mathrm{mg} / \mathrm{L}$ of BA instead of 2,4-D in WPM. Other than that, $0.5 \mathrm{mg} / \mathrm{L}$ NAA was reported to induce good callus in MS media (Wani et al., 2010) parallel with this research conducted using $0.5 \mathrm{mg} / \mathrm{L}$ that resulted in $95 \%$ callus induction using MS media.

On the other hand, $1.0 \mathrm{mg} / \mathrm{L}$ NAA $+0.2 \mathrm{mg} / \mathrm{L}$ 2,4-D and $5.0 \mathrm{mg} / \mathrm{L} \mathrm{NAA}+0.2 \mathrm{mg} / \mathrm{L}$ 2,4-D showed the lowest callus induction which is $10 \%$ in MS media while the treatment of $5.0 \mathrm{mg} / \mathrm{L}$ $\mathrm{NAA}+0.5 \mathrm{mg} / \mathrm{L}$ 2,4-D in WPM showed the lowest callus induction which is only by $5 \%$. Nevertheless, the low reading of callus induction can also be seen in Osman et al., (2016) where even with $1.5 \mathrm{mg} / \mathrm{L}$ of 2,4-D were able to record only $5 \%$ of callus induction. From the results shown in Table 1, the highest concentration of 2,4-D used was $0.5 \mathrm{mg} / \mathrm{L}$, and for both media, the callus induced was average compared to $0.2 \mathrm{mg} / \mathrm{L}$ that recorded maximum callus induction. Similar findings were also found in are search conducted by Lima et al., (2008), which stated that the combination of NAA and 2,4-D were unable to induce a great amount of callus for Croton urucurana Bail, which is a traditional medicinal plant.

However, the explants treated with $1.0 \mathrm{mg} / \mathrm{L}$ NAA $+0.2 \mathrm{mg} / \mathrm{L}$ 2,4-D on MS media showed minimal browning, while the explants cultured on WPM with similar treatment showed no sign of browning at all. Based on the results in Table 1 for browning of callus, the severity of the browning can be indicated by ++++ $(100 \%),+++(70 \%$ to $90 \%),++(40 \%$ to $60 \%),+(10 \%$ to $30 \%)$ and $-(0 \%)$ or no browning detected. For both media, the browning increase gradually when the NAA concentration increased with a fixed concentration of $0.5 \mathrm{mg} / \mathrm{L} 2,4-\mathrm{D}$, and the intensity of browning peaked at $5.0 \mathrm{mg} / \mathrm{L}$ of NAA. The findings can be supported by Ren et al., (2020) that stated the browning of callus were severe in either MS media or WPM with similar treatment as in this research which is $0.5 \mathrm{mg} / \mathrm{L}$ of 2,4-D. Still, instead of the combination of NAA and 2,4-D, Ren et al. (2020) used TDZ and 2,4-D. Although 2,4-D are useful in inducing 
International Journal of Agriculture and Environmental Research

ISSN: 2455-6939

Volume: 07, Issue: 02 "March-April 2021"

callus but in high concentration, 2,4-D may cause ethylene evolution that increased the callus' browning. According to Baharan et al., (2010), plant growth regulators that worked on date palm, emphasizing 2,4-D increase browning in date palm callus. Furthermore, the result can be further supported by Song, (2014) stated that 2,4-D and also NAA greatly increase ethylene production, which worsen browning and as seen in the results shown in Table 1, where a higher concentration of NAA and 2,4-D showed greater browning compared to the lower concentration of treatment.

\section{Callus proliferation and regeneration of Lepisanthes fruticosa}

The proliferated callus that initiated from the treatment of $0.2 \mathrm{mg} / \mathrm{L} 2,4-\mathrm{D}+1.0 \mathrm{mg} / \mathrm{L} \mathrm{NAA}$ and $0.2 \mathrm{mg} / \mathrm{L} 2,4-\mathrm{D}+0.5 \mathrm{mg} / \mathrm{L}$ NAA were cultured with a different type of growth regulators such as Gibberellic Acid (GA3), Benzylaminopurine (BAP) and Kinetin with different concentrations $(0.5$ and $1.0 \mathrm{mg} / \mathrm{L})$. Generally, in the result, Kinetin's presence showed a major factor contributing to regeneration success without browning incidence. Among treatments involving $0.2 \mathrm{mg} / \mathrm{L} 2,4-\mathrm{D}+1.0 \mathrm{mg} / \mathrm{L} \mathrm{NAA}$ and $0.2 \mathrm{mg} / \mathrm{L} 2,4-\mathrm{D}+0.5 \mathrm{mg} / \mathrm{L}$ NAA with $0.5 \mathrm{mg} / \mathrm{L} \mathrm{Kinetin}$ showed the highest number of regenerated plantlets which are 12 plantlets and 21 plantlets, respectively. Increasing the concentration of Kinetin at $1.0 \mathrm{mg} / \mathrm{L}$ decreasing the number of plantlets. The highest percentage of proliferation was found involving $0.2 \mathrm{mg} / \mathrm{L} 2,4-\mathrm{D}+0.5$ $\mathrm{mg} / \mathrm{L}$ NAA with $0.5 \mathrm{mg} / \mathrm{L}$ Kinetin at $100 \%$ while for $0.2 \mathrm{mg} / \mathrm{L}$ 2,4-D + $1.0 \mathrm{mg} / \mathrm{L}$ NAA, $70 \%$ proliferation succeeded as the highest (Table 2) (Figure 1c-d).

For callus initial involving $0.2 \mathrm{mg} / \mathrm{L} 2,4-\mathrm{D}+1.0 \mathrm{mg} / \mathrm{L}$ NAA, the embryos greening was recorded to be the highest at $0.5 \mathrm{mg} / \mathrm{L}$ Kinetin which is $60 \%$ corresponding to $0.2 \mathrm{mg} / \mathrm{L} 2,4-\mathrm{D}+0.5 \mathrm{mg} / \mathrm{L}$ NAA, the highest embryos greening was also recorded at $0.5 \mathrm{mg} / \mathrm{L}$ Kinetin $(80 \%)$ (Figure 1e-g). Callus treated with BAP showed intense browning after 3 cycles of sub-culturing (Figure $1 \mathrm{~h}$ ) in both concentration $(0.5 \mathrm{mg} / \mathrm{L}$ and $1.0 \mathrm{mg} / \mathrm{L})$ and from both treatments $(0.2 \mathrm{mg} / \mathrm{L} 2,4-\mathrm{D}+1.0$ $\mathrm{mg} / \mathrm{L} \mathrm{NAA}$ and $0.2 \mathrm{mg} / \mathrm{L} 2,4-\mathrm{D}+0.5 \mathrm{mg} / \mathrm{L}$ NAA). In addition, there was no plantlets observed in the treatment and obtained the least percentage of proliferation from both callus initial 0.2 $\mathrm{mg} / \mathrm{L} 2,4-\mathrm{D}+1.0 \mathrm{mg} / \mathrm{L}$ NAA and $0.2 \mathrm{mg} / \mathrm{L} 2,4-\mathrm{D}+0.5 \mathrm{mg} / \mathrm{L}$ NAA $(50 \%)$. This study found that the treatment involving $0.2 \mathrm{mg} / \mathrm{L} 2,4-\mathrm{D}+0.5 \mathrm{mg} / \mathrm{L}$ NAA with $0.5 \mathrm{mg} / \mathrm{L}$ Kinetin specifically allowed rapid proliferation and most of the embryos turned green or yellowish with zero browning after 3 cycles of sub-culturing and regenerated the highest number of plantlets (Table 2) (Figure 1i-k). The shoots were left until they reach a height of 6-8 cm (Figure 11-m). The acclimatization of plantlets in ex vitro conditions was carried out with the plants bearing transferred to small pots containing soil mixtures (organic soil, garden soil, sand, 1:1:0.5). They were maintained at about $70 \%$ relative humidity in the greenhouse with $75 \%$ shading. A survival rate $90 \%$ was achieved after 6 weeks (Figure 1n). 
International Journal of Agriculture and Environmental Research

ISSN: 2455-6939

Volume: 07, Issue: 02 "March-April 2021"

In the finding, Kinetin is the most crucial plant growth regulators to promote plant regeneration and cell proliferation compared to the others. The maximum number of regenerated plantlets produced is when treated with $0.5 \mathrm{mg} / \mathrm{LKinetin}$ (Figure 11-m). Minocha et al. (1987) supported that cytokinins are commonly used complemented with auxins for callus initiation and maintenance of callus cultures with appropriate concentrations. A combination of Kinetin and auxin also induced shoot regeneration from callus in several woody angiosperms. It is reiterated by Barciszewski, J. et al. (1999), who stated that Kinetin (N6- furfuryladenine) is a cytokinin that induces cell division and organogenesis in plant cell cultures. However, contradict toOkazawa et al. (1976), which reported that Kinetin is not necessary for callus formation and development as callus growth was observed even without Kinetin in the media. Still, it has a significant effect on the initiation of root formation.

The results showed that the browning occurs after three cycles of subculturing in the medium supplemented with BAP. Furthermore, there was zero number of regenerated plantlets were observed in the media containing BAP in both callus initial from $0.2 \mathrm{mg} / \mathrm{L} 2,4-\mathrm{D}+1.0 \mathrm{mg} / \mathrm{L}$ NAA and $0.2 \mathrm{mg} / \mathrm{L} 2,4-\mathrm{D}+0.5 \mathrm{mg} / \mathrm{L}$ NAA. This is supported by Baharan et al. (2015), who reported that concentrations of plant growth regulators, including BAP, showed a significant effect on browning. Baharan et al. (2015) also added that the higher the BAP concentration, the more browning incidence in date palm, which is also categorized as woody plants.

According to Irshad et al. (2017), browning of callus that is caused by phenolic secretion is observed to be one of the factors that adversely affect woody plants' regeneration, specifically okra plants in the study. Injuries during explants isolation triggered the oxidation of phenolic compounds, which resulted in the browning of explants and eventually led to death, which supported the findings that zero regenerated plantlets were observed in the treatment complemented with BAP. The phenolic oxidation was believed to be initiated by the Polyphenol oxidase (PPO) enzyme (Larson, 1988) and other oxidative enzymes, which include phenylalanine ammonia-lyase (PAL) and peroxidase (POD) (Andersone and Levinsh, 2002; Tabiyeh et al., 2005). A range of culture manipulations has been designed to reduce PPO and POD incidence on phenolic compound oxidation and the effects of oxidized phenolic compounds on tissue culture (Irshad et al., 2017). These include culturing explants initially in the dark (Da Silva et al., 2015), transfer the explants to fresh medium at short gaps (Lloyd and McCown 1980), include antioxidants in the culture medium (Meziani et al., 2016) and adsorbents (Klenoticová et al., 2013), or soaking explants in water or solutions containing antioxidants preceding to inoculation (Gupta et al., 1980). 
International Journal of Agriculture and Environmental Research

ISSN: 2455-6939

Volume: 07, Issue: 02 "March-April 2021"

Table 1: Effect of various NAA and 2,4-D concentration on the induction of callus in Lepisanthes fruticosa cultured on MS and WPM media

\begin{tabular}{cccccc}
\hline $\begin{array}{c}\text { Type of } \\
\text { media }\end{array}$ & $\begin{array}{c}\text { NAA } \\
(\mathrm{mg} / \mathrm{L})\end{array}$ & $\begin{array}{c}2,4-\mathrm{D} \\
(\mathrm{mg} / \mathrm{L})\end{array}$ & $\begin{array}{c}\text { Callus } \\
\text { induction } \\
(\%)\end{array}$ & $\begin{array}{c}\text { Weight of } \\
\text { callus }\end{array}$ & $\begin{array}{c}\text { Browning (after } \\
\text { onemonthsub- } \\
\text { culture) }\end{array}$ \\
\hline \multirow{6}{*}{ MS } & 0 & 0.2 & 10 & $3.1 \pm 0.6$ & ++ \\
& 0.5 & 0.2 & 95 & $3.5 \pm 0.3$ & + \\
& 1.0 & 0.2 & 100 & $4.6 \pm 0.4$ & + \\
& 3.0 & 0.2 & 60 & $1.0 \pm 0.1$ & +++ \\
& 5.0 & 0.2 & 10 & $1.2 \pm 0.1$ & +++ \\
\hline & 0 & 0.5 & 40 & $3.0 \pm 0.1$ & + \\
& 0.5 & 0.5 & 70 & $3.9 \pm 0.7$ & + \\
& 1.0 & 0.5 & 70 & $2.7 \pm 0.5$ & ++ \\
& 3.0 & 0.5 & 60 & $2.6 \pm 0.6$ & +++ \\
& 5.0 & 0.5 & 40 & $1.4 \pm 0.5$ & ++++ \\
\hline \multirow{5}{*}{ WPM } & 0 & 0.2 & 20 & $2.0 \pm 0.3$ & ++ \\
& 0.5 & 0.2 & 70 & $5.3 \pm 1.1$ & - \\
& 1.0 & 0.2 & 100 & $7.7 \pm 0.5$ & - \\
& 3.0 & 0.2 & 30 & $4.5 \pm 0.4$ & ++ \\
& 5.0 & 0.2 & 30 & $4.9 \pm 0.9$ & ++ \\
& 0 & 0.5 & 30 & $4.9 \pm 1.0$ & + \\
& 0.5 & 0.5 & 50 & $4.1 \pm 1.2$ & ++ \\
& 1.0 & 0.5 & 50 & $2.4 \pm 0.5$ & ++ \\
& 3.0 & 0.5 & 20 & $1.0 \pm 0.3$ & ++++ \\
& 5.0 & 0.5 & 5 & $0.9 \pm 0.1$ & ++++ \\
\hline
\end{tabular}

Results represent mean of 25 replicates; \pm standard error mean (SEM)

Severity of browning: $++++(100 \%),+++(70 \%$ to $90 \%),++(40 \%$ to $60 \%),+(10 \%$ to $30 \%),-(0 \%)$ or no browning detected 
International Journal of Agriculture and Environmental Research

ISSN: 2455-6939

Volume: 07, Issue: 02 "March-April 2021"

Table 2: Effect of 2,4-D and BAP on callus proliferation and regeneration of Lepisanthes fruticosa cultured on WPM media.

\begin{tabular}{|c|c|c|c|c|c|}
\hline $\begin{array}{l}\text { Callus } \\
\text { initial }\end{array}$ & $\begin{array}{l}\text { Sub-culture } \\
\text { treatments } \\
(\mathrm{mg} / \mathrm{L})\end{array}$ & $\begin{array}{l}\text { Proliferation } \\
\qquad(\%) \\
\text { (first sub- } \\
\text { culture) }\end{array}$ & $\begin{array}{c}\text { Embryos } \\
\text { greening/ } \\
\text { yellowish } \\
(\%)\end{array}$ & $\begin{array}{c}\text { Browning } \\
\text { after } 3 \text { cycles } \\
\text { of sub- } \\
\text { culturing }\end{array}$ & $\begin{array}{c}\text { Number of } \\
\text { regenerated } \\
\text { plantlets }\end{array}$ \\
\hline \multirow{9}{*}{$\begin{array}{c}0.2 \mathrm{mg} / \mathrm{L} \\
2,4-\mathrm{D} \\
+1.0 \\
\mathrm{mg} / \mathrm{L} \\
\mathrm{NAA}\end{array}$} & GA3 & & & & \\
\hline & 0.5 & $80 \pm 15$ & $50 \pm 10$ & + & 7 \\
\hline & 1.0 & $80 \pm 12$ & $40 \pm 5$ & + & 6 \\
\hline & $\underline{\mathrm{BAP}}$ & & & & \\
\hline & 0.5 & $50 \pm 10$ & $20 \pm 5$ & +++ & 0 \\
\hline & 1.0 & $50 \pm 4$ & 0 & +++ & 0 \\
\hline & Kin & & & & \\
\hline & 0.5 & $70 \pm 5$ & $60 \pm 12$ & - & 12 \\
\hline & 1.0 & $60 \pm 13$ & $60 \pm 6$ & - & 9 \\
\hline \multirow{9}{*}{$\begin{array}{c}0.2 \mathrm{mg} / \mathrm{L} \\
2,4-\mathrm{D}+0.5 \\
\mathrm{mg} / \mathrm{L} \\
\mathrm{NAA}\end{array}$} & $\underline{\mathrm{GA} 3}$ & & & & \\
\hline & 0.5 & $80 \pm 10$ & $30 \pm 3$ & - & 6 \\
\hline & 1.0 & $70 \pm 5$ & $10 \pm 5$ & + & 4 \\
\hline & BAP & & & & \\
\hline & 0.5 & $50 \pm 5$ & $10 \pm 5$ & ++ & 0 \\
\hline & 1.0 & $50 \pm 10$ & 0 & +++ & 0 \\
\hline & $\underline{\text { Kin }}$ & & & & \\
\hline & 0.5 & $100 \pm 15$ & $80 \pm 5$ & - & 21 \\
\hline & 1.0 & $100 \pm 5$ & $70 \pm 3$ & - & 15 \\
\hline
\end{tabular}

Results represent mean of 25 replicates; \pm standard error mean (SEM) 
International Journal of Agriculture and Environmental Research

ISSN: 2455-6939

Volume: 07, Issue: 02 "March-April 2021"

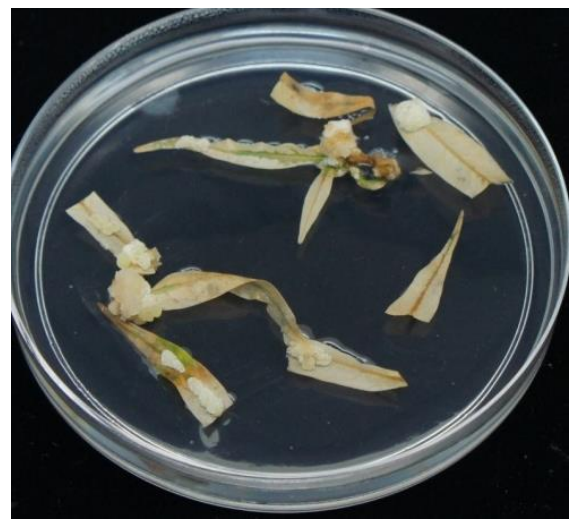

a

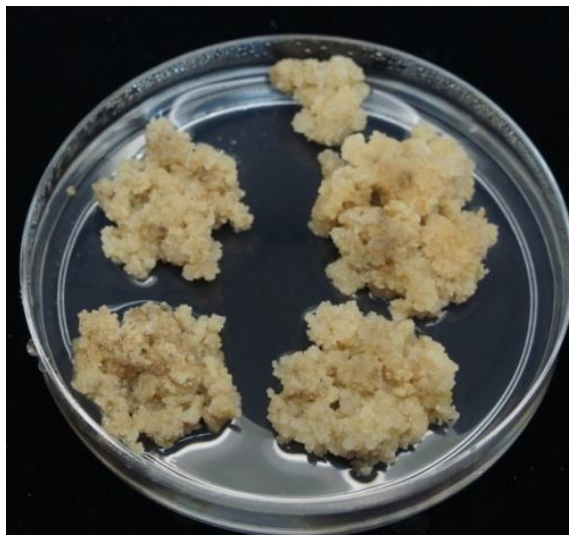

C

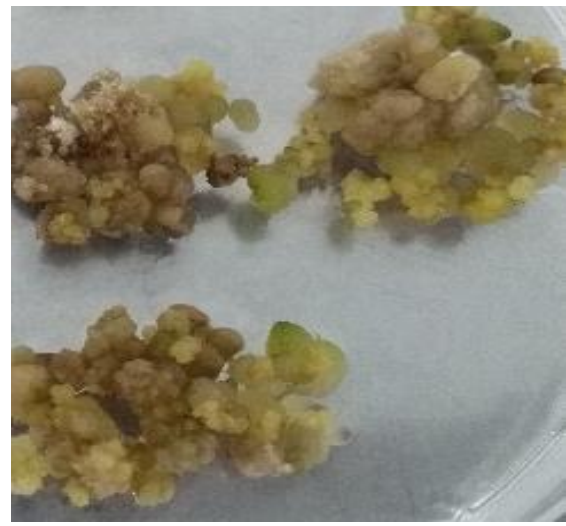

e

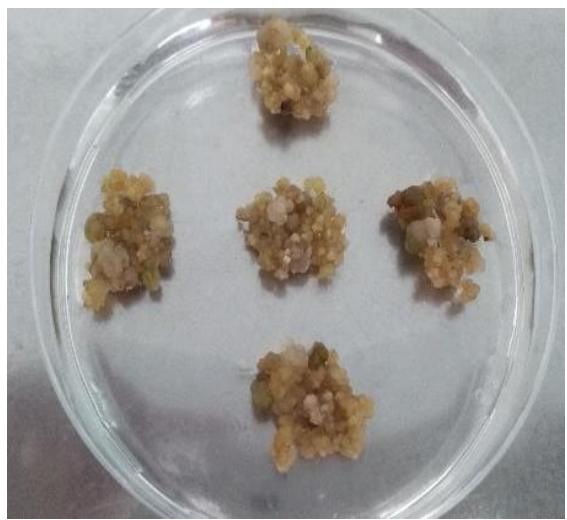

b

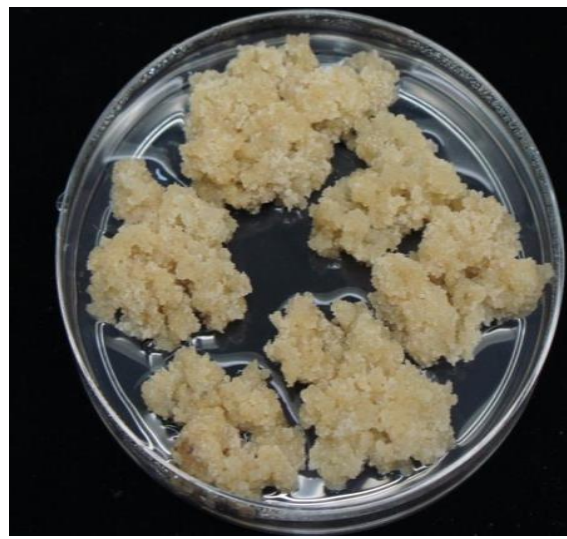

d

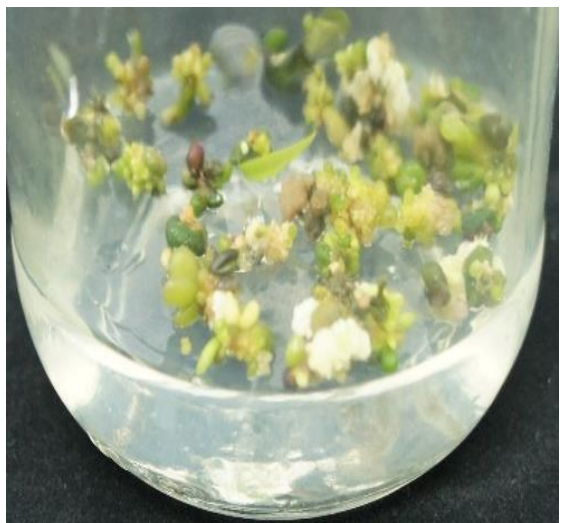

f 
International Journal of Agriculture and Environmental Research

ISSN: 2455-6939

Volume: 07, Issue: 02 "March-April 2021"

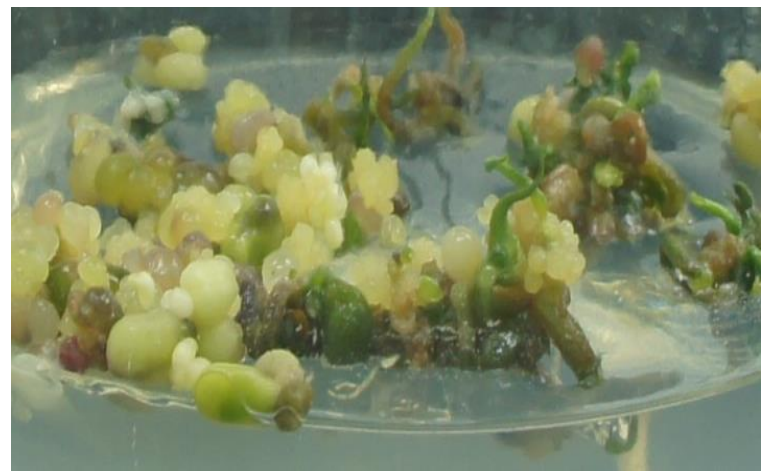

g

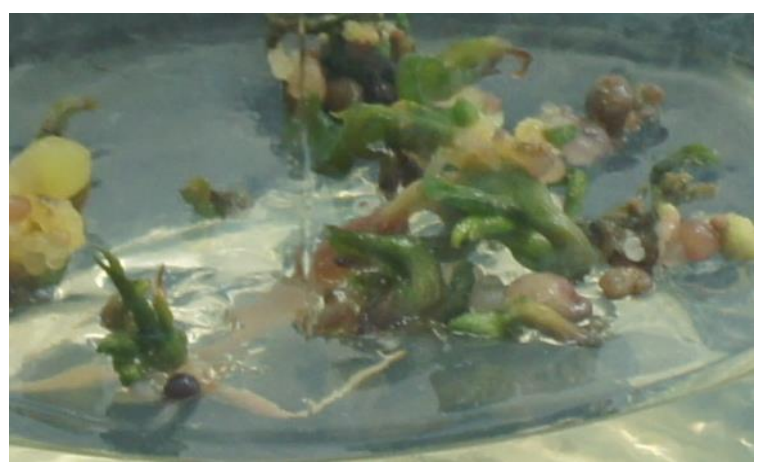

i

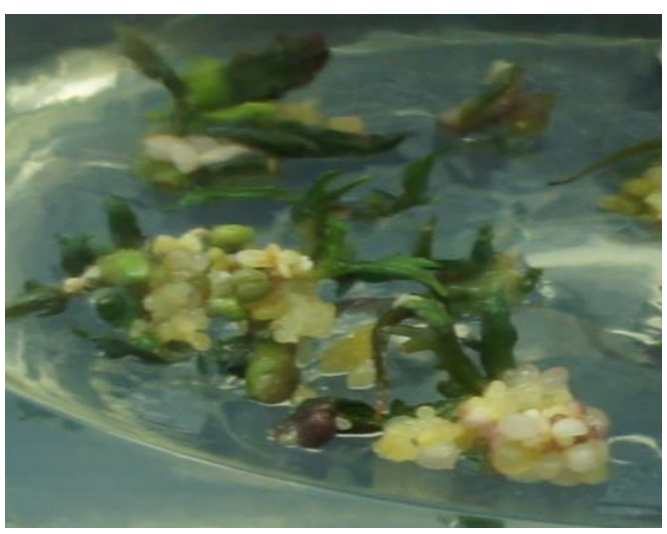

k

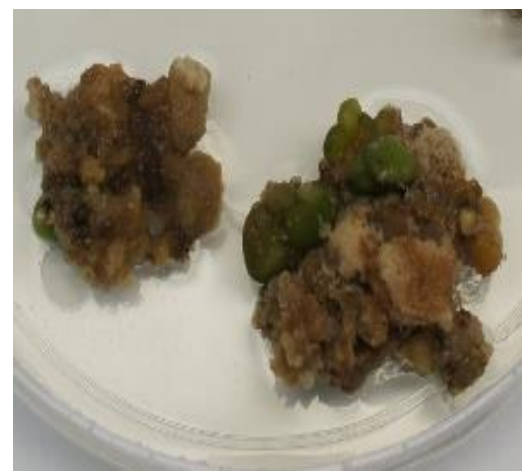

h

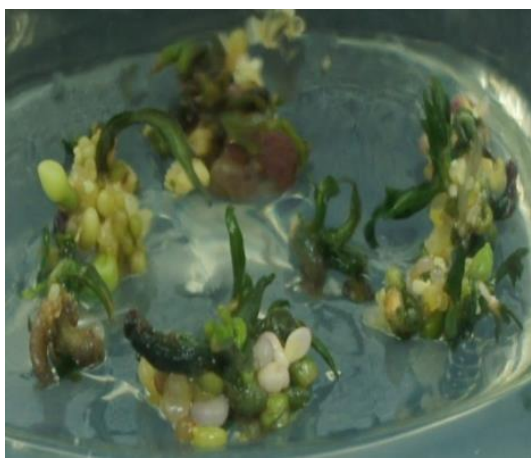

j

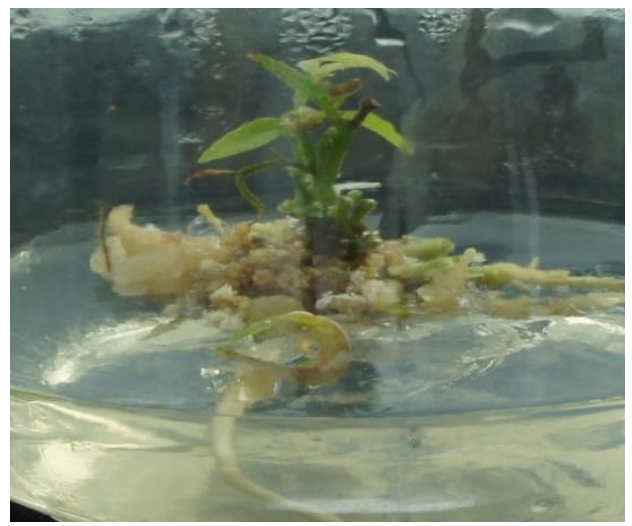

। 


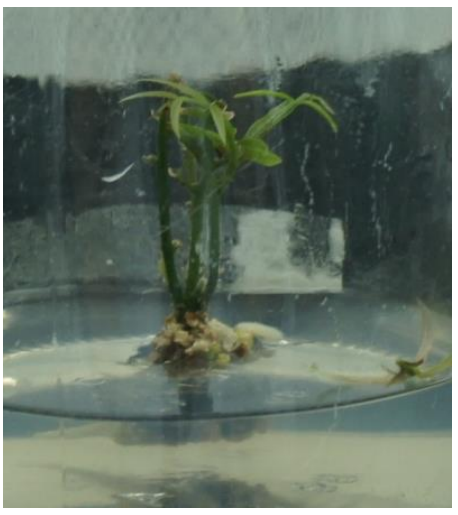

$\mathrm{m}$

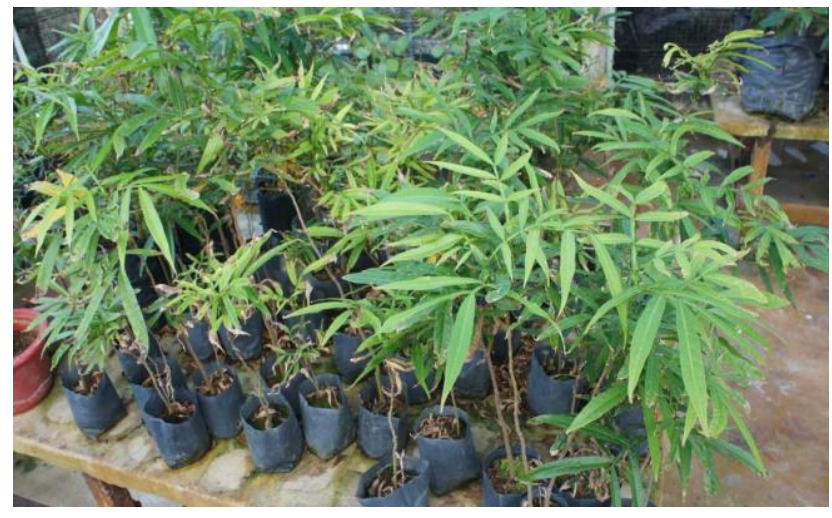

n

Figure 1: Callus induction and plant regeneration in Lepisanthes fruticose (a) Leaves of Lepisanthes fruticosa raised in vitro were cut into lengths of 2-3, (b) Callus induction initiated on medium containing treatment of $1.0 \mathrm{mg} / \mathrm{L} \mathrm{NAA}+0.2 \mathrm{mg} / \mathrm{L} \mathrm{2,4-D,} \mathrm{(c,d)}$ Proliferation callus, (e,f,g) Callus turning green on $0.5 \mathrm{mg} / \mathrm{L}$ Kinetin, (h) Callus treated with BAP showed intense browning after 3 cycles of sub-culturing, $(i, j, k)$ regenerated plantlets, embryos turned green and shoot produced, $(1, \mathrm{~m})$ complete plantlets with roots and (n) Plantlets transferred into polybag.

\section{CONCLUSION}

In conclusion, the plant regeneration method of Lepisanthes fruticosa has been developed along with a suitable concentration for callus induction that involves treatment containing $1.0 \mathrm{mg} / \mathrm{L}$ $\mathrm{NAA}+0.2 \mathrm{mg} / \mathrm{L} 2,4-\mathrm{D}$ on either MS media or WPM. However, the WPM media for $1.0 \mathrm{mg} / \mathrm{L}$ $\mathrm{NAA}+0.2 \mathrm{mg} / \mathrm{L} 2,4-\mathrm{D}$ and $0.5 \mathrm{mg} / \mathrm{L} \mathrm{NAA}+0.2 \mathrm{mg} / \mathrm{L} 2,4-\mathrm{D}$ showed no browning hence was proceed with proliferation and regeneration. The treatment of $0.5 \mathrm{mg} / \mathrm{L}$ kinetin to the initial callus of $1.0 \mathrm{mg} / \mathrm{L} \mathrm{NAA}+0.2 \mathrm{mg} / \mathrm{L} 2,4-\mathrm{D}$ resulted in no browning with the highest number of regenerated plantlets that is 12 . Furthermore, the treatment with yet again $0.5 \mathrm{mg} / \mathrm{L}$ kinetin with the initial callus from the induction of $0.5 \mathrm{mg} / \mathrm{L} \mathrm{NAA}+0.2 \mathrm{mg} / \mathrm{L} \mathrm{2,4-D}$ showed no sign of browning with 21 plantlets regenerated. 21 plantlets are the highest number of plantlets regenerated for the $0.5 \mathrm{mg} / \mathrm{L} \mathrm{NAA}+0.2 \mathrm{mg} / \mathrm{L} \mathrm{2,4-D}$ callus initial. The regeneration of plantlets for Lepisanthes fruticosa is crucial in providing a better understanding of its species. Consequently, it leads to discovering more of the potential of this plant. 
International Journal of Agriculture and Environmental Research

ISSN: 2455-6939

Volume: 07, Issue: 02 "March-April 2021"

\section{REFERENCES}

1. Minocha, S. C. (1987). Plant growth regulators and morphogenesis in cell and tissue culture of forest trees. In Cell and tissue culture in forestry (pp. 50-66). Springer, Dordrecht.

2. Okazawa, Y., Katsura, N., \& Tagawa, T. (1967). Effects of auxin and kinetin on the development and differentiation of potato tissue cultured in vitro. Physiologia Plantarum, 20(4), 862-869.

3. Gupta PK, Nadgir AL, Mascarenhas AF, Jagannathan V (1980) Plant Science Lett. 17: $259-268$

4. Lloyd G, McCo n B (lq80) Comb. Proc. I n t 1. Plant Prop. Soc. 30: 421-427

5. Da Silva ALL, Gollo AL, Brondani GE, Horbach MA, De Oliveira LS, Machado MP, De Lima KKD, Costa JDL (2015) Micropropagation of Eucalyptus saligna Sm. from cotyledonary nodes. Pak J Bot 47:311-318

6. Meziani R, Jaiti F, Mazri MA, Hassani A, Salem SB, Anjarne M, Chitt MA, Alem C (2016) Organogenesis of Phoenix dactylifera

7. L. cv. Mejhoul: Influences of natural and synthetic compounds on tissue browning, and analysis of protein concentrations and peroxidase activity in explants. Sci Hortic 204:145152

8. Klenotičová H, Smýkalová I, Švábová L, Griga M (2013) Resolving browning during the establishment of explant cultures in Vicia faba L. for genetic transformation. Acta Univ Agric Silvic Mendelianae Brun 61:1279-1288

9. Baharan, E., Mohammadi, P. P., Shahbazi, E., \& Hosseini, S. Z. (2015). Effects of some plant growth regulators and light on callus induction and explants browning in date palm (Phoenix dactylifera L.) in vitro leaves culture. Iranian Journal of Plant Physiology, 5(4), 1473-1481.

10. Andersone U, Ievinsh G (2002) Changes of morphogenic competence in mature Pinus sylvestris L. buds in vitro. Ann Bot 90:293-298

11. Tabiyeh D, Bernard F, Shacker H (2005) Investigation of glutathione, salicylic acid and GA3 effects on browning in Pistacia vera shoot tips culture. Acta Hortic ISHS 726:201-204

12. Larson RA (1988) The antioxidants of higher plants. Phytochemistry 27:969-978

13. Balzan, S., Johal, G. S., \&Carraro, N. (2014). The role of auxin transporters in monocots development. Frontiers in Plant Science, 5. doi:10.3389/fpls.2014.00393

14. Barciszewski, J., Rattan, S. I., Siboska, G., \& Clark, B. F. (1999). Kinetin -45 years on. Plant science, 148(1), 37-45.

15. Hedden, P. (2017). Gibberellins. Encyclopedia of Applied Plant Sciences, 411-420. doi:10.1016/b978-0-12-394807-6.00219-7 
International Journal of Agriculture and Environmental Research

ISSN: 2455-6939

Volume: 07, Issue: 02 "March-April 2021"

16. Ab Rahman, Z., Shukri Mat Ali, M., Norfaizal Ghazalli, M., Awang, K., \& Nazreena Othman, A. (2018). Optimization of Culture Media Formulations for Micropropagation of Lepisanthes fruticosa. Biosciences, Biotechnology Research Asia, 15(1), 51-58. https://doi.org/10.13005/bbra/2607

17. Anas, M. (2020). International Journal of Agriculture, Forestry and Plantation, Vol. 10 (Sept) ISSN 2462-1757 2020. 10.

18. Baharan, E., Mohammadi, P. P., Shahbazi, E., \& Hosseini, S. Z. (2010). Effects of some plant growth regulators and light on callus induction and explants browning in date palm ( Phoenix dactylifera L.) in vitro leaves culture. June, 1473-1482.

19. Lim, T. K. (2013). Edible medicinal and non-medicinal plants: Volume 6, fruits. Edible Medicinal and Non-Medicinal Plants: Volume 6, Fruits, 6, 1-606. https://doi.org/10.1007/978-94-007-5628-1

20. Lima, E. C., Paiva, R., Nogueira, R. C., Soares, F. P., Emrich, E. B., \& Silva, Á. A. N. (2008). Callus induction in leaf segments of Croton urucurana Baill. Ciência $e$ Agrotecnologia, 32(1), 17-22. https://doi.org/10.1590/s1413-70542008000100002

21. Looi, S. K., Zainol, M. K., Mohd, Z. Z., Hamzah, Y., \& Mohdmaidin, N. (2020). Antioxidant and antibacterial activities in the fruit peel, flesh and seed of Ceri Terengganu (Lepisanthes Alata leenh.). Food Research, 4(5), 1600-1610. https://doi.org/10.26656/fr.2017.4(5).172

22. M.S, M. (2013). In vitro Micropropagation of Selected Bougainvillea sp. through callus induction. IOSR Journal of Agriculture and Veterinary Science, 6(6), 01-06. https://doi.org/10.9790/2380-0660106

23. Osman, N. I., Jaafar Sidik, N., \& Awal, A. (2016). Effects of variations in culture media and hormonal treatments upon callus induction potential in endosperm explant of Barringtonia racemosa L. Asian Pacific Journal of Tropical Biomedicine, 6(2), 143-147. https://doi.org/10.1016/j.apjtb.2015.10.007

24. Ren, X., Liu, Y., \& Jeong, B. R. (2020). Callus induction and browning suppression in tree peony Paeonia ostii 'Fengdan.' Horticulture Environment and Biotechnology, 61(3), 591600. https://doi.org/10.1007/s13580-020-00246-6

25. Song, Y. (2014). Insight into the mode of action of 2,4-dichlorophenoxyacetic acid (2,4-D) as an herbicide. Journal of Integrative Plant Biology, 56(2), 106-113. https://doi.org/10.1111/jipb.12131

26. Wani, M., Pande, S., \& More, N. (2010). Callus induction studies in Tridax procumbens L. International Journal of Biotechnology Applications, 2(1), 11-14. https://doi.org/10.9735/0975-2943.2.1.11-14 